\title{
Effects of dietary trans-fatty acids on reproductive performance of Wistar rats
}

\author{
BY T. HANIS ${ }^{1}$, V. ZIDEK ${ }^{1}$, J. SACHOVA ${ }^{2}$, P. KLIR ${ }^{1}$ AND Z. DEYL \\ ${ }^{1}$ Institute of Physiology, Czechoslovak Academy of Sciences, Prague, Czechoslovakia \\ ${ }^{2}$ Research Institute of Animal Production, Prague, Czechoslovakia
}

(Received 21 November 1988 - Accepted 30 November 1988)

\begin{abstract}
1. Wistar rats were fed for three successive generations on a semi-purified diet, in which the fat was provided by butter, sunflower oil, rapeseed oil or hydrogenated vegetable fat, differing in the content of cis,cis-18:2 and trans-18:1 fatty acids. Effects of these fats on the composition of adipose tissue and reproductive performance were studied. Fatty acids were analysed using high-performance liquid chromatography.

2. The fatty acid pattern of adipose tissue was closely related to dietary fat composition and, established in the first generation, did not change significantly in successive generations of rats.

3. Hydrogenated fat adversely affected litter size, sperm morphology and regularity of oestrous cycle, and prolonged the period of gestation in experimental animals. Differences observed between the generations were not significant.

4. Hydrogenated fat decreased the level of serum testosterone in males, but the differences observed in levels of serum progesterone in females were not apparently related to the dietary trans-fatty acids.
\end{abstract}

Fats are important constituents of our diet and, beside their functions as sources of energy and carriers for fat-soluble vitamins, they supply essential fatty acids that are vital components of cell membranes (Hansen \& Jensen 1985), and precursors for potent hormone-like compounds such as prostaglandins and leukotrienes (Gorman, 1979; Lewis \& Austen, 1981; Walker, 1983; Mead, 1984).

Widespread use of partially hydrogenated vegetable oils containing large amounts of trans-fatty acid has raised questions concerning the biological effects of consumption of significant amounts of these isomers (Alfin-Slater et al. 1965). Although biochemical and physiological research on isomeric fatty acids in hydrogenated oils have substantially increased the understanding of their metabolism, there is still no absolute consensus on the role of isomeric fats in nutrition and health (Emken, 1983). One aspect of trans-fatty acids that has received great attention is their relation to essential fatty acid metabolism. Numbers of investigations in vivo have provided evidence that hydrogenated fats and specific fatty acid isomers can influence the activity of the desaturases, elongases, acyltransferases, oxygenases and prostaglandin synthetases (Emken, 1984). Particularly important is the ability of trans, trans-18:2 fatty acids to inhibit the elongation desaturation reactions of linoleic acid (Kurata \& Privett, 1980). Monoenoic trans-fatty acids may also undergo desaturation to dienoic acids in rat tissue, particularly if the animals are essentialfatty-acid deficient. Therefore, it is obvious that giving hydrogenated fat containing a high concentration of trans-18:1 acid may accentuate essential-fatty-acid deficiency in rats (Holman, 1964; Nugteren, 1970; Hill et al. 1979; Walker, 1983; Zevenbergen et al. 1988).

Since Burr \& Burr (1930) demonstrated the essentiality of linoleic acid in reproduction and growth of animals, a wide range of physiological functions has been shown to be affected by essential-fatty-acid deficiency (Holman, 1968, 1973; Alling et al. 1972; Cornwell \& Morisaki, 1984; Nugteren et al. 1985; Guesnet et al. 1986; Hansen, 1986). Impairment of reproductive functions is one of the earlier symptoms of the lack of essential fatty acids (Menon et al. 1981; Ravel et al. 1985).

It is well established that essential-fatty-acid deficiency in the rat leads to degeneration 
of the testis, with concomitant infertility, in males (Ahluwalia et al. 1967; Marzouki \& Coniglio, 1982). In females, though they may conceive, fetuses are often reabsorbed, animals abort or young ones are stillborn (Mohrhauer \& Holman, 1967; Menon et al. 1981); the frequency of irregular oestrous cycles, with an increased incidence of prolonged dioestrus, prolonged period of gestation, reduced litter size, and increased pup mortality, are usually significantly higher (Satomi \& Matsuda, 1973; Parlanti \& Orellana, 1985). It seems possible that high concentrations of trans-fatty acid isomers, as found in hydrogenated dietary oils, could also adversely affect the reproduction of laboratory rats, though that effect would be more probable at lower levels of essential fatty acids (Holman \& Aaes-Jorgensen, 1956; Alfin-Slater et al. 1957; Emken, 1984).

Dietary trans-fatty acids have been shown to be incorporated into many tissues (Johnston et al. 1958; Egwim \& Kummerow, 1972; Wood, 1979; Moore et al. 1980; Emken, 1984). Adipose tissue, known to accumulate high amounts of trans-fatty acids (Moore et al. 1980), is interesting in that chronic feeding of hydrogenated fat leads to elevation of lipogenic enzyme activity, although these enzymes are not apparently affected in other tissues, for example, liver (Wilck, 1982; Walker, 1983). Of interest also are the recent findings that conversion of androgens to oestrogens takes place in adipose tissue, which suggests that adipose tissue may be a significant extra-gonadal source of oestrogens (Frisch, 1984). Fatness and adipose tissue fatty acid pattern also influence the direction of oestrogen metabolism to the most potent or least potent forms (Fishman et al. 1975).

In the present study we have tried to evaluate possible effects of several dietary fats differing in their content of essential as well as trans-fatty acids on fatty acid profiles of adipose tissue and the reproductive performance of the Wistar rat in a multi-generation study.

\section{EXPERIMENTAL}

\section{Materials}

In the present experiment the following dietary fats were used: butterfat (BF), sunflower oil (SO), rapeseed oil (low in erucic acid content; $\mathrm{RO}$ ), hydrogenated vegetable oil (HO). These fats added were included at $50 \mathrm{~g} / \mathrm{kg}$ in an experimental semi-purified diet (SED) derived from the AIN 76 diet (American Institute of Nutrition, 1977) based on sucrose. As a control, diet DOS $2 b$ (Velaz, Prague), based on natural ingredients, was used. The composition of the diets and their fatty acid profiles are given in Tables 1 and 2. Diet HO contained the highest concentration of trans-18:1 and trans,trans $-18: 2$ fatty acids, approximately 19 and $3 \%$ of total fatty acids respectively. Diet BF contained the lowest concentration of cis,cis-18:2 fatty acid, approximately $2.9 \%$ of total fatty acids, while diet HO contained approximately $4 \%$, diet DOS $14 \%$, diet SO $64 \%$ and diet RO $22 \%$ of this fatty acid. These concentraticas represented 0.38 and $0.54 \%$ of total energy in diets BF and HO, $1.85 \%$ in diet DOS, $2.89 \%$ in diet RO and $8.35 \%$ in diet SO. The highest levels of cis18:1 fatty acid were found in diet HO, $45 \%$ and diet RO $56 \%$. The diets were prepared every two weeks and stored at $-18^{\circ}$.

\section{Animal experiments}

Weanling Wistar rats (100; Ipcv: WIST), weighing 40-60 g, were randomly allocated to five groups of ten males and ten females each. Rats were housed in groups of five animals of the same sex in polypropylene cages (Velaz, Prague).

All animals were fed $a d$ lib. and had free access to drinking water. Food intakes were measured weekly on a cage (five rats) basis. Body-weights were measured twice weekly.

After $85 \mathrm{~d}$ on their respective diets, six animals randomly selected from each group were fasted for $12 \mathrm{~h}$ and anaesthetized with Thiopental (Spofa, Prague; $50 \mathrm{mg} / \mathrm{kg}$ animal weight 
Table 1. Composition of the diets $(\mathrm{g} / \mathrm{kg})$

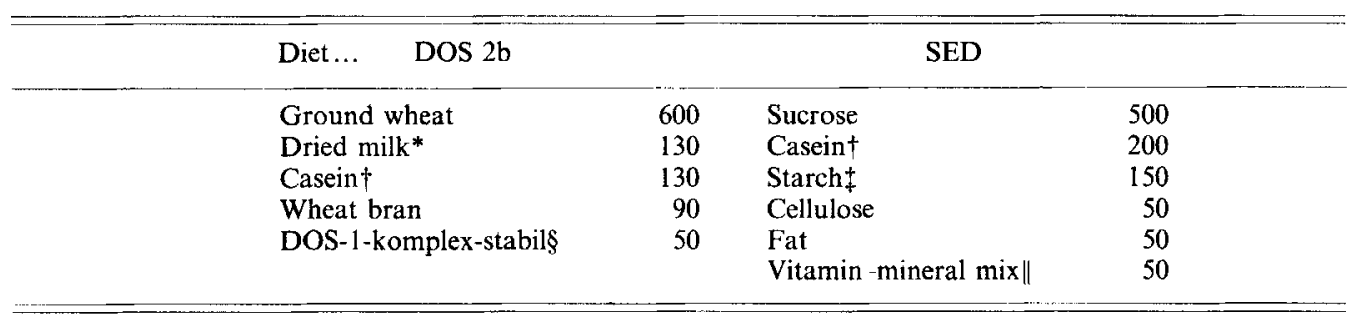

* Fat content $280 \mathrm{~g} / \mathrm{kg}$.

$\dagger$ Extracted (fat- and vitamin-free).

$\ddagger$ Potato starch.

$\S$ Vitamin content $(\mathrm{mg} / \mathrm{kg})$ : thiamin 240 , riboflavin 160 , pyridoxine 80 , cyanocobalamin 0.6 , vitamin $\mathrm{E} 2 \mathrm{~g}$, vitamin A 30, vitamin D 2.5, folic acid 120, calcium pantothenate 160 , inositol $2 \mathrm{~g}$. Mineral content $(\mathrm{g} / \mathrm{kg}): \mathrm{calcium}$ carbonate 84 , calcium phosphate 221 , sodium chloride 150 , ferrous sulphate 32 , cupric sulphate $392 \mathrm{mg}$, zinc sulphate $440 \mathrm{mg}$, manganous carbonate 2, potassium iodide $26 \mathrm{mg}$ (Velaz, Prague, Czechoslovakia).

\|V Vitamin content $(\mathrm{mg} / \mathrm{kg})$; thiamin 370 , riboflavin 282 , pyridoxine 200 , cyanocobalamin 0.8 , vitamin E 2.5 g, vitamin A 36, vitamin D 2.5, vitamin K 1.5, folic acid 131, calcium pantothenate $1.0 \mathrm{~g}$, inositol $4.3 \mathrm{~g}$, biotin 5 , nicotinic acid $1.3 \mathrm{~g}$, choline chloride $23 \mathrm{~g}$, L-methionine $72 \mathrm{~g}$. Mineral content $(\mathrm{g} / \mathrm{kg})$ : calcium carbonate 92 , calcium phosphate (dibasic) 340 , sodium chloride 164 , ferrous sulphate 35 , cuprous sulphate $427 \mathrm{mg}$, zinc sulphate $479 \mathrm{mg}$, manganous carbonate $207 \mathrm{mg}$, potassium iodide $29 \mathrm{mg}$, magnesium sulphate (heptahydrate) 196, potassium chloride 166 , sodium selenite $8 \mathrm{mg}$, sodium fluoride $22 \mathrm{mg}$, potassium chromate $109 \mathrm{mg}$.

Table 2. Fatty acid composition of dietary fats (weight $\%$ total fatty acids)

\begin{tabular}{|c|c|c|c|c|c|c|}
\hline $\begin{array}{c}\text { Fatty } \\
\text { acid }\end{array}$ & Diet*. & DOS & BF & SO & RO & $\mathrm{HO}$ \\
\hline $8: 0$ & & 1.66 & 3.45 & 0.18 & 0.06 & 0.12 \\
\hline $12: 0$ & & $2 \cdot 32$ & 4.76 & 0.86 & $0 \cdot 35$ & 0.76 \\
\hline $14: 0$ & & 6.78 & 10.97 & 0.06 & 0.05 & 0.37 \\
\hline $14: 1$ & & 0.79 & 1.49 & - & - & $0-02$ \\
\hline $16: 0$ & & $21 \cdot 14$ & $30 \cdot 44$ & $6 \cdot 11$ & $5 \cdot 18$ & $8 \cdot 89$ \\
\hline $16: 1$ & & $2 \cdot 24$ & 3.29 & 0.14 & $0 \cdot 32$ & 0.82 \\
\hline $18: 0$ & & $7 \cdot 14$ & $10 \cdot 21$ & $3 \cdot 72$ & $1 \cdot 71$ & $8 \cdot 11$ \\
\hline$c-18: 1$ & & $18 \cdot 29$ & $23 \cdot 16$ & $21 \cdot 45$ & $56 \cdot 23$ & $45 \cdot 22$ \\
\hline$t-18: 1$ & & 1.34 & 3.05 & - & - & $19 \cdot 45$ \\
\hline$c c-18: 2$ & & $14 \cdot 24$ & $2 \cdot 90$ & $64 \cdot 23$ & $22 \cdot 26$ & $4 \cdot 13$ \\
\hline$t t-18: 2$ & & 0.43 & 0.98 & - & - & $3 \cdot 19$ \\
\hline $18: 3$ & & $2 \cdot 55$ & $2 \cdot 22$ & 2.02 & $10 \cdot 54$ & 1.52 \\
\hline $20: 0$ & & 0.05 & - & 034 & $0 \cdot 17$ & 0.19 \\
\hline$c-20: 1$ & & 0.45 & $0 \cdot 24$ & $0 \cdot 12$ & 0.06 & $0 \cdot 10$ \\
\hline $20: 2$ & & $2 \cdot 00$ & - & & & \\
\hline $20: 3$ & & 0.37 & - & 0.63 & 0.37 & 0.39 \\
\hline $22: 1$ & & - & - & - & $0 \cdot 33$ & - \\
\hline
\end{tabular}

$c$, cis-isomer; $t$, trans-isomer; DOS, control diet; BF, butterfat; SO, sunflower oil; RO, rapeseed oil low in erucic acid; $\mathrm{HO}$, hydrogenated vegetable oil.

* For details of DOS (DOS 2b; Velaz, Prague) and diets BF, SO, RO and HO (semi-purified experimental diet $+50 \mathrm{~g} \mathrm{BF}, \mathrm{SO}, \mathrm{RO}$ or $\mathrm{HO} / \mathrm{kg}$ respectively), see Table $\mathrm{l}$ and p. 520 .

intraperitoneally). Blood samples for progesterone and testosterone determinations were taken from the inferior vena cava and stored at $-18^{\circ}$ until analysis.

Liver, kidney, heart and testis and epididymis or ovary were then removed, washed in cooled saline $(9 \mathrm{~g}$ sodium chloride/l) and wet weighed. Samples of adipose tissue were taken from the linea alba abdominal subcutaneous region and fatty-acid profiles were analysed. 
The remaining animals, four males and four females in each group, were then mated $1: 1$ in a cage. The number of newborn pups were reduced to eight for each dam with sexes equalized. At the age of $35 \mathrm{~d}$ the animals were weaned and their number was again reduced to ten males and ten females in each dietary group by random selection. These animals were kept on their respective diets to the age of $85 \mathrm{~d}$, and then treated in the same manner as their parents. The procedures were repeated so that three successive generations of the rats on the same experimental diets could be investigated. The experiment was repeated during the following year with new animals in the same months to avoid seasonal differences in physiological activities of the animals. In both cases, F1 generation animals were born in February, F2 generation in May, and F3 generation in September. In all, 600 Wistar rats were used in the experiment.

\section{Lipid analysis}

Lipids from adipose tissue were extracted by the method of Folch et al. (1957), using methanol - chloroform $(2: 1, \mathrm{v} / \mathrm{v})$ and a solvents: tissue value of $20: 1$. Fatty acid profiles of the lipid extracts were analysed by high-performance liquid chromatography after derivatization of fatty acids with phenacyl bromide (Hanis et al. 1986, 1988).

\section{Reproduction tests}

The percentage of pregnant females and the litter size were recorded for each dietary group and nest. The age of vaginal opening was determined by daily observations. The age of the first oestrus and regularity of the oestrous cycle were determined from daily vaginal smears. Rats with three consecutive regular, $4 \mathrm{~d}$, oestrous cycles were considered as regularoestrous-cycle rats. The length of pregnancy was calculated from the first day of spermatozoa presence in the vaginal fluid smear. The morphological abnormality of spermatozoa was determined by staining with Giemsa-Romanowski reagent (Washington et al. 1983); 400 sperm were used for mean value calculations. Plasma concentrations of progesterone and testosterone were determined by radioimmunoassay (Abraham, 1974).

\section{Statistical analysis}

The Student-Newman-Keuls multiple-range test (Miller, 1981) was used for evaluation of the significance of the differences between experimental groups.

\section{RESULTS AND DISCUSSION}

During the experimental period the animals showed no apparent symptoms of nutritional deficiency. Feed intakes between 32 and $85 \mathrm{~d}$ increased from 14 to $23 \mathrm{~g} / \mathrm{d}$ for males, and from 14 to $21 \mathrm{~g} / \mathrm{d}$ for females; no significant differences related to the diets were observed.

Body-weight gains are presented in Figs 1 and 2. The lower weights of the rats fed on diets $\mathrm{BF}$ or $\mathrm{HO}$, with the proportion of energy derived from cis,cis-18:2 fatty acid at the lower margin of rat requirement (as determined by Pudelkewicz et al. (1968)) were observed at the end of the experiment. However, these weights were not significantly different from those of rats in the other dietary groups. No significant differences were observed in the weights and gross pathology or morphology of hearts, livers, kidneys, testes, epididimides and ovaries. These results are in agreement with the observations of other workers conducting long-term and multiple-generation studies with rats fed on hydrogenated fats (Alfin-Slater et al. 1957; Alfin-Slater \& Aftergood, 1979; Duthie \& Barlow; 1982; Kritchevsky, 1982; Svaar, 1982; Zevenbergen et al. 1988).

Fatty-acid profiles of adipose tissue fat of animals fed on different diets are summarized in Table 3. These profiles were related to the fatty-acid composition of dietary fats (Table 2), demonstrating that adipose tissue fatty acid reflects dietary fat intake (Emken, 1983). 


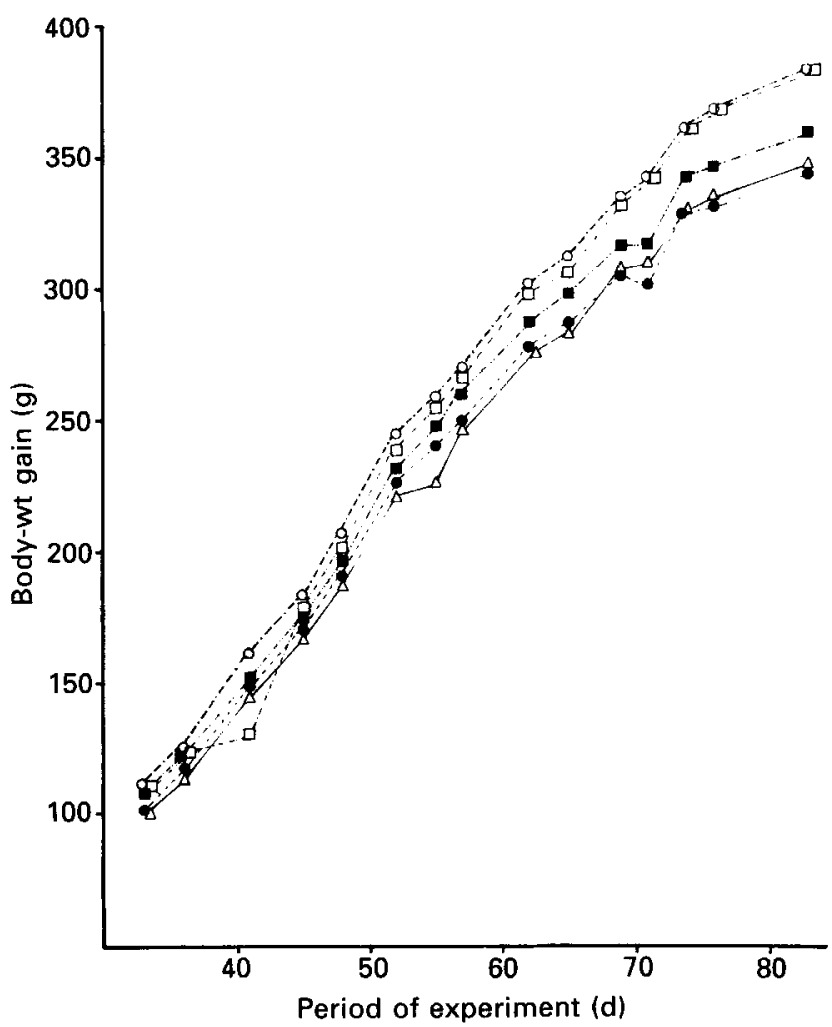

Fig. 1. Body-weight gains of male Wistar rats fed on different dietary fats. (O), Control diet (DOS); butterfat; $(\square)$, sunflower oil; $(\square)$, rapeseed oil; $(\triangle)$, hydrogenated oil. For details of control diet DOS and diets containing different dietary fats, see p. 520 . Standard errors of the means: $0.80(32-45 \mathrm{~d}), 1.39$ $(48-57 \mathrm{~d}), 2.03(62-85 \mathrm{~d})$.

That dietary trans-fatty acids are incorporated into both depot and structural fats has been well documented (Egwim \& Kummerow 1972; Emken, 1984). We found significantly higher concentrations $(P<0.05)$ of trans-18:1 and trans,trans-18:2 fatty acids in adipose tissue of animals fed on diets HO and BF than those of the animals on the other diets. The highest concentrations of these isomers were observed in diet $\mathrm{HO}$ rats : approximately $15 \%$ of trans-18:1 and $2 \%$ of trans,trans-18:2. Adipose tissue of the animals on diet BF contained approximately $2 \%$ of trans-18:1 and 1\% of trans,trans-18:2. Traces of these trans-fatty acids were also detected in adipose tissue of animals fed on diets free of transfatty acids, which may indicate a possible endogenous source for a small proportion of trans-isomers, also observed in human tissues (Ohlrogge et al. 1982). Animals fed on diets HO or BF also exhibited significantly lower concentrations of cis,cis-18:2 and all-cis-20:4 fatty acids, and significantly higher concentrations of $20: 1$ and $20: 3$ fatty acids, as compared with the animals in other dietary groups. The lowest content of cis,cis-18:2 fatty acid was found in adipose tissue of rats fed on diet BF, which reflects the low content of linoleic acid in diet BF. The lowest content of all-cis-20:4 fatty acid was found in the group given diet $\mathrm{HO}$, probably because the highest concentrations of various fatty-acid isomers were found in $\mathrm{HO}$, and through the possible interference of these isomers with the metabolic pathway of linoleic (cis,cis-9,12-18:2) and arachidonic (all-cis-5,8,11,14-20:4) acids (Nugteren, 1970; Kurata \& Privett, 1980; Mahfouz et al. 1980; Walker, 1983). Though a 


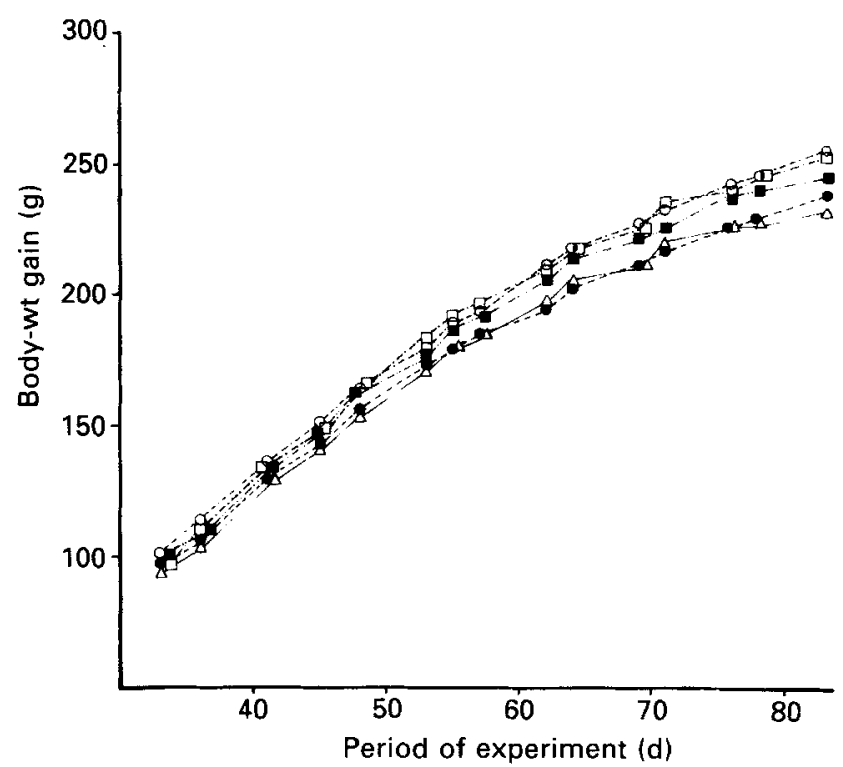

Fig. 2. Body-weight gains of female Wistar rats fed on different dietary fats. (O), Control diet (DOS); (O), butterfat; $(\square)$, sunflower oil ; $(\square)$, rapeseed oil ; $\triangle$ ), hydrogenated oil. For details of control diet DOS and diets containing different dietary fats, see p. 520 . Standard errors of the means: $0 \cdot 79(32-45$ d), $1 \cdot 10(48-57 \mathrm{~d}), 1 \cdot 50(62-85 \mathrm{~d})$.

decrease in linoleic and arachidonic acids is usually observed in animals fed on essentialfatty-acid-deficient and high-trans-fatty-acid diets, our findings suggest that even giving a hydrogenated-fat diet alone could affect the tissue concentration of arachidonic and linoleic acids. Our observations seem to be in line with previous reports suggesting similar changes in the fatty-acid composition of tissues of animals fed on partially hydrogenated fats, even with a supply of about $4 \%$ of linoleic acid (Kirstein et al. 1983, Thomassen et al. 1983). No significant differences were observed in fatty acid profiles between males and females, or between the successive generations of the rats on their respective diets. The fatty-acid composition of adipose tissue established during the $85 \mathrm{~d}$ in the first generation of rats was found to be unchanged in the following generations.

Giving diet $\mathrm{HO}$ to Wistar rats resulted in significantly increased incidences of irregular oestrous cycles and prolonged gestation periods, compared with other dietary groups. Half the females on diet $\mathrm{HO}$ exhibited irregular oestrous cycles compared with $25 \%$ for females given diets BF or RO, and those fed on diets DOS or SO showed a regular $4 \mathrm{~d}$ oestrous cycle. Dams fed on diet HO had prolonged gestation periods: over $22 \mathrm{~d}$ in $50 \%$ of the dams while, with diet DOS, only in $9 \%$ was the gestation period longer than $22 \mathrm{~d}$, and with diets $\mathrm{BF}$, SO and RO only $19-20 \%$. Each group consisted of sixty females.

There were no statistically significant differences among the dietary groups in the age of vaginal opening and the age of the first oestrus, but the animals fed on diets $\mathrm{HO}$ or BF usually showed higher mean values for these variables. First oestrus onset occurred at the age of 37.7 (SE 1.5)-41.2 (SE 2.8) d, which was 4-6 d after the vaginal opening. Also, no significant differences were observed in the fecundity rate of females fed on these diets. The mean number of pregnant females after $48 \mathrm{~h}$ mating was about $85 \%$.

The average size of litters in diet HO group was significantly smaller than that for the other diets $(P<0.05)$, as may be seen in Table 4 . The differences among the other dietary groups were not statistically significant. 
Table 3. Main fatty acid profiles of adipose tissue of Wistar rats fed on different dietary fats (weight \% total fatty acids)

(Mean values with their standard errors)

\begin{tabular}{|c|c|c|c|c|c|c|c|c|c|c|}
\hline \multirow{2}{*}{$\begin{array}{r}\text { Diet } \dagger \ldots \\
\text { Fatty acid }\end{array}$} & \multicolumn{2}{|c|}{ DOS } & \multicolumn{2}{|c|}{$\mathrm{BF}$} & \multicolumn{2}{|c|}{ SO } & \multicolumn{2}{|c|}{ RO } & \multicolumn{2}{|c|}{$\mathrm{HO}$} \\
\hline & Mean & $\mathrm{SE}$ & Mean & SE & Mean & $\mathrm{SE}$ & Mean & $\mathrm{SE}$ & Mean & $\mathrm{SE}$ \\
\hline $12: 0$ & $2 \cdot 03$ & 0.042 & $1 \cdot 18$ & $0 \cdot 013$ & 1.65 & 0.022 & 0.40 & 0.011 & $0 \cdot 29$ & $0 \cdot 008$ \\
\hline $14: 0$ & 6.80 & 0.131 & 4.86 & 0.052 & $7 \cdot 76$ & 0.026 & 1.96 & 0.022 & $2 \cdot 70$ & 0.023 \\
\hline $14: 1$ & 0.62 & 0.016 & 0.77 & 0.013 & 0.45 & 0.020 & 0.69 & 0.022 & $0 \cdot 30$ & 0.005 \\
\hline $16: 0$ & $30-01$ & 0.063 & $29 \cdot 25$ & 0.105 & $28 \cdot 12$ & 0.556 & 27.88 & 0.145 & $25 \cdot 35$ & 0.129 \\
\hline $16: 1$ & $13 \cdot 12$ & 0.016 & 13.93 & $0 \cdot 109$ & $9 \cdot 69$ & 0.132 & $9 \cdot 26$ & 0.087 & $12 \cdot 78$ & 0.066 \\
\hline $18: 0$ & $4 \cdot 15$ & 0.019 & 2.55 & 0.035 & $5 \cdot 81$ & $0 \cdot 120$ & $4 \cdot 33$ & 0.041 & $3 \cdot 27$ & 0.023 \\
\hline$c-18: 1$ & $33-08$ & 0.067 & $40 \cdot 27$ & 0.147 & 34.08 & 0.423 & 44.71 & 0.134 & $32 \cdot 40$ & 0.052 \\
\hline$t-18: 1$ & 0.96 & 0.021 & $2 \cdot 17^{*}$ & $0-016$ & 0.47 & $0 \cdot 031$ & 0.33 & 0.011 & $15 \cdot 60^{*}$ & 0.048 \\
\hline$c c-18: 2$ & $5 \cdot 12$ & 0.060 & $1.68^{*}$ & 0.056 & $8 \cdot 70$ & 0.051 & 6.56 & 0.060 & $2 \cdot 10^{*}$ & 0.017 \\
\hline$t t-18: 2$ & 0.50 & 0.005 & $1 \cdot 10^{*}$ & 0.013 & $0 \cdot 37$ & 0.019 & 0.44 & 0.023 & $2 \cdot 18^{*}$ & 0.019 \\
\hline $18: 3$ & 1.35 & 0.040 & $0.14^{*}$ & $0-004$ & $0 \cdot 62$ & 0.005 & $1 \cdot 32$ & 0.015 & $0 \cdot 29^{*}$ & 0.005 \\
\hline$c-20: 1$ & 020 & 0.008 & $0.60^{*}$ & $0-004$ & $0 \cdot 12$ & $0 \cdot 004$ & 0.15 & 0.004 & $0.79^{*}$ & 0.017 \\
\hline $20: 3$ & 0.49 & 0.007 & $1.06^{*}$ & 0.010 & 0.43 & 0.008 & 0.38 & 0.010 & $1.59^{*}$ & 0.012 \\
\hline $20: 4$ & 0.32 & 0.008 & $0.20^{*}$ & 0.005 & 0.46 & 0.011 & 0.44 & 0.008 & $0.12^{*}$ & 0.005 \\
\hline $22: 1$ & $\ldots$ & & - & & - & & 0.25 & 0.004 & - & \\
\hline $22: 6$ & 1.25 & 0.011 & $0 \cdot 24$ & 0.011 & 1.27 & 0.014 & 0.90 & 0.008 & 0.24 & 0.010 \\
\hline
\end{tabular}

$c$, is-isomer; $t$, trans-isomer; DOS, control diet; BF, butterfat ; SO, sunflower oil; RO, rapeseed oil low in erucic acid; HO, hydrogenated vegetable oil.

* Mean values in the same horizontal rows were significantly different from values for diets DOS, SO, RO $(P<0.05)$.

$\dagger$ For details of DOS (DOS $2 b$; Velaz, Prague) and diets BF, SO, RO and HO (semi-purified experimental diet $+50 \mathrm{~g} \mathrm{BF}, \mathrm{SO}, \mathrm{RO}$ or $\mathrm{HO} / \mathrm{kg}$ respectively), see Table 1 and $\mathrm{p} .520$.

Table 4. Litter size of rats fed on different fats (no. of new born pups for a dam) (Mean values with their standard errors)

\begin{tabular}{|c|c|c|c|c|c|c|}
\hline \multirow{2}{*}{$\begin{array}{l}\text { Generation ... } \\
\text { Diet } t\end{array}$} & \multicolumn{2}{|c|}{$\mathrm{Fl}(n 12) \ddagger$} & \multicolumn{2}{|c|}{$\mathrm{F} 2(n 12) \ddagger$} & \multicolumn{2}{|c|}{$\mathrm{F} 3\left(\begin{array}{ll}n 20)_{\ddagger}^{+} \\
-\end{array}\right.$} \\
\hline & Mean & $\mathrm{SE}$ & Mean & $\mathrm{SE}$ & Mean & SE \\
\hline DOS & $12 \cdot 0$ & 0.61 & $10 \cdot 9$ & 0.66 & $10 \cdot 4$ & 0.51 \\
\hline $\mathrm{BF}$ & 11.0 & 0.64 & $10 \cdot 8$ & 0.72 & $9 \cdot 4^{\mathrm{a}}$ & 0.40 \\
\hline SO & 110 & 0.90 & $10 \cdot 3$ & 0.87 & $10 \cdot 3$ & 0.56 \\
\hline RO & $10 \cdot 4$ & 0.38 & $10 \cdot 6$ & 0.52 & $10 \cdot 9$ & 0.45 \\
\hline $\mathrm{HO}$ & $8.5 *$ & 0.75 & $8-0^{*}$ & $0 \cdot 78$ & $8 \cdot 8^{*}$ & 0.63 \\
\hline
\end{tabular}

DOS, control diet; BF, butterfat; SO, sunflower oil; RO, rapeseed oil low in erucic acid; HO, hydrogenated vegetable oil.

* Mean values in the same vertical column were significantly different from other values, except the value marked 'a' $(P<0 \cdot 05)$.

$\dagger$ For details of DOS (DOS 2b; Velaz, Prague) and diets BF, SO, RO and HO (semi-purified experimental diets $+50 \mathrm{~g} \mathrm{BF}, \mathrm{SO}, \mathrm{RO}$ or $\mathrm{HO} / \mathrm{kg}$ respectively), see Table $\mathrm{I}$ and $\mathrm{p} .520$.

$\ddagger$ No. of dams.

In males fed on diet $\mathrm{HO}$ a significantly higher incidence of abnormal sperm morphology occurred as compared with males on diet DOS $(P<0.05)$. Differences among other dietary groups were not statistically significant (Table 5 ).

The levels of serum concentrations of progesterone and testosterone of the experimental rats are summarized in Tables 6 and 7 . The concentration of testosterone was significantly 
Table 5. Incidence (\%) of abnormal morphology of spermatozoa of male rats fed on different dietary fats

(Mean values with their standard errors)

\begin{tabular}{|c|c|c|c|c|c|c|}
\hline \multirow{2}{*}{$\begin{array}{l}\text { Generation ... } \\
\text { Diet } \uparrow\end{array}$} & \multicolumn{2}{|c|}{ FI $(n 20) t$} & \multicolumn{2}{|c|}{$\mathrm{F} 2\left(\begin{array}{ll}n & 20) \ddagger\end{array}\right.$} & \multicolumn{2}{|c|}{ F3 $(n 40) \ddagger$} \\
\hline & Mean & $\mathrm{SE}$ & Mean & $\mathrm{SE}$ & Mean & $\mathrm{SE}$ \\
\hline DOS & 6.8 & $0 \cdot 20$ & $7 \cdot 1$ & $0 \cdot 29$ & $6 \cdot 3$ & 0.33 \\
\hline $\mathrm{BF}$ & $7 \cdot 8$ & 0.18 & $8 \cdot 2$ & 0.43 & 8.9 & 0.59 \\
\hline SO & $7 \cdot 1$ & $0 \cdot 36$ & $6 \cdot 2$ & 0.36 & $9 \cdot 2$ & 0.52 \\
\hline RO & $7 \cdot 3$ & 0.31 & $5 \cdot 9$ & $0 \cdot 36$ & $7 \cdot 6$ & $0 \cdot 38$ \\
\hline $\mathrm{HO}$ & $9 \cdot 2^{*}$ & 0.31 & $9 \cdot 8^{*}$ & 0.53 & $12.5^{*}$ & 0.84 \\
\hline
\end{tabular}

DOS, control diet; BF, butterfat; SO, sunflower oil; RO, rapeseed oil low in erucic acid; HO, hydrogenated vegetable oil.

* Mean values in the same vertical column were significantly different from other values $(P<0 \cdot 05)$.

$\uparrow$ For details of DOS (DOS 2b; Velaz, Prague) and diets BF, SO, RO and HO (semi-purified experimental diets $+50 \mathrm{~g} \mathrm{BF}, \mathrm{SO}, \mathrm{RO}$ or $\mathrm{HO} / \mathrm{kg}$ respectively), see Table 1 and p. 520 .

$\ddagger$ No. of males. Age of animals $85 \mathrm{~d}$.

Table 6. Serum concentration of progesterone $(\mathrm{ng} / \mathrm{ml})$ in female Wistar rats fed on different dietary fats

(Mean values with their standard errors)

\begin{tabular}{|c|c|c|c|c|c|c|}
\hline \multirow{2}{*}{$\begin{array}{l}\text { Generation ... } \\
\text { Diet* }\end{array}$} & \multicolumn{2}{|c|}{ F1 $(n 12) \dagger$} & \multicolumn{2}{|c|}{$\mathbf{F} 2(n 12) \dagger$} & \multicolumn{2}{|c|}{$\mathrm{F} 3(n 20) \dagger$} \\
\hline & Mean & $\mathrm{SE}$ & Mean & $\mathrm{SE}$ & Mean & $\mathrm{SE}$ \\
\hline DOS & 13.85 & $2 \cdot 48$ & $18 \cdot 00$ & 2.41 & $13 \cdot 24$ & $2 \cdot 09$ \\
\hline BF & 5.83 & 0.96 & $16 \cdot 26$ & 1.81 & 6.15 & 0.88 \\
\hline SO & $16 \cdot 23$ & 2.64 & $19 \cdot 40$ & $2 \cdot 71$ & $10 \cdot 67$ & $1 \cdot 15$ \\
\hline RO & $7 \cdot 47$ & 0.99 & $17 \cdot 19$ & 2.41 & 7.96 & 0.78 \\
\hline $\mathrm{HO}$ & 7.84 & 1.73 & $16 \cdot 13$ & $9 \cdot 32$ & $6 \cdot 36$ & 497 \\
\hline
\end{tabular}

DOS, control diet; BF, butterfat; SO, sunflower oil; RO, rapeseed oil low in erucic acid; HO, hydrogenated vegetable oil.

* For details of DOS (DOS 2b; Velaz, Prague) and diets BF, SO, RO and HO (semi-purified experimental diets $+50 \mathrm{~g} \mathrm{BF}, \mathrm{SO}, \mathrm{RO}$ or $\mathrm{HO} / \mathrm{kg}$ respectively), see Table 1 and p. 520 .

$\dagger$ No. of females. Age of animals $85 \mathrm{~d}$.

$(P<0.05)$ lower in males on diets $\mathrm{HO}$ or BF than in other dietary groups. The concentrations of progesterone in females showed a wide dispersion of values, which makes statistical evaluation impossible. Contrary to all other observations the concentration also tended to be higher in the second generation than in the first or the third generations of the females, for which we can find no reasonable explanation. There seems to be no direct relation with the dietary content of linoleic acid or trans-fatty acids.

It is well documented that lack of essential fatty acids impairs the reproductive functions of mammals (Menon et al. 1981). So far the only studies with hydrogenated fat that reported differences in reproduction were those in which hydrogenated fats were given to essential-fatty-acid-deficient rats (Holman \& Aaes-Jorgensen, 1956; Alfin-Slater et al. 1957; Emken, 1984), though trans-octadecenoic acid interference with the linoleic acid metabolic pathway was observed in vitro, even in animals fed on essential-fatty-acidsufficient diets (Kirstein et al. 1983). The symptoms observed in our experiment, such as prolonged gestation period, reduced litter size and irregular oestrous cycle in the diet HO- 
Table 7. Serum concentration of testosterone $(\mathrm{ng} / \mathrm{ml})$ in male Wistar rats fed on different dietary fats

(Mean values with their standard errors)

\begin{tabular}{|c|c|c|c|c|c|c|}
\hline \multirow{2}{*}{$\begin{array}{l}\text { Generation... } \\
\text { Diet } \dagger\end{array}$} & \multicolumn{2}{|c|}{$\mathrm{F} 1(n 20) \ddagger$} & \multicolumn{2}{|c|}{$\mathrm{F} 2(n 20)+$} & \multicolumn{2}{|c|}{$\mathrm{F} 3(n 40) \ddagger$} \\
\hline & Mean & $\mathrm{SE}$ & Mean & $\mathrm{SE}$ & Mean & $\mathrm{SE}$ \\
\hline DOS & $8 \cdot 38$ & 0.25 & $8 \cdot 68$ & 0.22 & $9 \cdot 24$ & 0.16 \\
\hline $\mathrm{BF}$ & $4 \cdot 20^{*}$ & 0.13 & $5 \cdot 60^{*}$ & $0 \cdot 19$ & $6 \cdot 20^{*}$ & 0.17 \\
\hline SO & 7.67 & $0 \cdot 22$ & $7 \cdot 34$ & 0.39 & 8.68 & 0.29 \\
\hline RO & $6 \cdot 15$ & 0.25 & $7 \cdot 25$ & 0.36 & 8.95 & 0.18 \\
\hline $\mathrm{HO}$ & $2 \cdot 80^{*}$ & 0.15 & $3 \cdot 20^{*}$ & 0.21 & $3 \cdot 54^{*}$ & $0 \cdot 14$ \\
\hline
\end{tabular}

DOS, control diet; BF, butterfat; SO, sunflower oil; RO, rapeseed oil low in erucic acid; HO, hydrogenated vegetable oil.

* Mean values in the same vertical column were significantly different from other values $(P<0-05)$.

$\dagger$ For details of DOS (DOS 2b; Velaz, Prague) and diets BF, SO, RO and HO (semi-purified experimental diets $+50 \mathrm{~g} \mathrm{BF}, \mathrm{SO}, \mathrm{RO}$ or $\mathrm{HO} / \mathrm{kg}$ respectively), see Table 1 and p. 520 .

+ No. of males. Age of animals $85 \mathrm{~d}$.

fed group are usual essential-fatty-acid-deficiency symptoms (Waltman et al. 1978; Parlanti \& Orellana, 1985; Guesnet et al. 1986), though diet HO was not essential-fatty-acid deficient.

In conclusion, it would be of great importance to explore intakes of dietary essential fatty acids that would prevent adverse effects of various partially hydrogenated dietary fats on the reproductive performance of animals, because it seems probable that essential fattyacid intakes considered sufficient at low dietary intakes of hydrogenated oils may substantially differ from essential fatty-acid requirements of animals consuming high amounts of hydrogenated oils.

The authors thank Dr J. Vorlicek for statistical evaluation of the experimental results.

\section{REFEREN CES}

Abraham, G. E. (1974). Radioimmunoassay of steroids in biological materials. Acta Endocrinologica 183, Suppl., $1-42$.

Ahluwalia, B., Pincus, G. \& Holman, R. T. (1967). Essential fatty acid deficiency and its effects upon reproductive organs of male rabbits. Journal of Nutrition 92, 205-214.

Alfin-Slater, R. B. \& Aftergood, L. (1979). Nutritional role of hydrogenated fats (in rats). In Geometrical and Positional Fatty Acid Isomers, pp. 53-74 [E. A. Emken and H. J. Dutton, editors]. Champaign, Ill. : American Oil Chemists' Society.

Alfin-Slater, R. B., Morris, R. S., Hansen, H. \& Proctor, J. F. (1965). Effects of non-essential fatty acids on essential fatty acid deficiency. Journal of Nutrition 87, 168-172.

Alfin-Slater, R. B., Wells, A. F., Aftergood, L. \& Deuel, H. J. Jr. (1957). Nutritive value and safety of hydrogenated vegetable fats as evaluated by long-term feeding experiments with rats. Journal of Nutrition 63 , 241-261.

Alling, C., Bruce, A., Karlsson, I., Sapia, O. \& Svennerholm, L. (1972). Effects of maternal essential fatty acid supply on fatty acid composition of brain, liver, muscle and serum in 21-day-old-rats. Journal of Nutrition 102 , $773-782$

American Institute of Nutrition. (1977). Report of the AIN Ad Hoc Committee on standards for nutritional studies. Journal of Nutrition 107, $1340-1348$.

Burr, G. O. \& Burr, M. M. (1930). On the nature and the role of the fatty acids essential in nutrition. Journal of Biological Chemistry 86, 587-621.

Cornwell, D. G. \& Morisaki, N. (1984). Fatty acid paradoxes in the control of cell proliferation: prostaglandins, lipid peroxides, and cooxidation reactions. In Free Radicals in Biology, vol. 6, pp. 95-148. New York: Academic Press. 
Duthie, I. F. \& Barlow, S. M. (1982). A rat life span study comparing partially hydrogenated fish oil, partially hydrogenated soybean oil and rapeseed oil included in the diet at high levels: outline description and interim communication. In Nutritional Evaluation of Long-Chain Fatty Acids in Fish Oil, pp. 185-214, [S. M. Barlow and M. E. Stansby, editors]. London: Academic Press.

Egwim, P. O. \& Kummerow, F. A. (1972). Incorporation and distribution of dietary elaidate in the major lipid classes of rat heart and plasma lipoproteins. Journal of Nutrition 102, 783-792.

Emken, E. A. (1983). Biochemistry of unsaturated fatty acid isomers. Journal of the American Oil Chemists' Society 60, 995-1004.

Emken, E. A. (1984). Nutrition and biochemistry of trans and positional fatty acid isomers in hydrogenated oils. Annual Reviews of Nutrition 4, 339-376.

Fishman, J., Boyar, R. M. \& Hellman, L. (1975). Influence of body weight on estradiol metabolism in young women. Journal of Clinical Endocrinology and Metabolism 41, 989-991.

Folch, J., Lees, M. \& Sloane-Stanley, G. H. (1957). A simple method for the isolation and purification of total lipides from animal tissues. Journal of Biological Chemistry 226, 497-509.

Frisch, R. E. (1984). Body fat, puberty and fertility. Biological Reviews 59, 161-188.

Gorman, R. R. (1979). Modulation of human platelet function by prostacyclin and thromboxane A2. Federation Proceedings 38, 83-88.

Guesnet, Ph., Pascal, G. \& Durand, G. (1986). Dietary $\alpha$-linolenic acid deficiency in the rat. I. Effects on reproduction and postnatal growth. Reproduction, Nutrition, Développement 26, 969-985.

Hanis, T., Smrz, M., Klir, P., Macek, K. \& Deyl, Z. (1986). Improved separation of C12-C22 fatty acid phenacyl esters by reversed phase column liquid chromatography. Collection of Czechoslovak Chemical Communications 51, 2722-2726.

Hanis, T., Smrz, M., Klir, P., Macek, K., Klima, J., Base, J. \& Deyl, Z. (1988). Determination of fatty acids as phenacyl esters by HPLC in rat adipose tissue and blood vessel wall. Journal of Chromatography 452, $443-457$.

Hansen, H. S. (1986). The essential nature of linoleic acid in mammals. Trends in Biochemical Sciences 11, 263-265.

Hansen, H. S. \& Jensen, B. (1985). Essential function of linoleic acid esterified in acylglucosylceramide and acylceramide in maintaining the epidermal permeability barrier. Biochimica et Biophysica Acta 834, 357-363.

Hill, E. G., Johnson, S. B. \& Holman, R. T. (1979). Intensification of essential fatty acid deficiency in the rat by dietary trans-fatty acids. Journal of Nutrition 109, 1759-1766.

Holman, R. T. (1964). Nutritional and metabolic interrelationship between fatty acids. Federation Proceedings 23, 1062-1067.

Holman, R. T. (1968). Essential fatty acid deficiency. In Progress in the Chemistry of Fats and Other Lipids, vol. 9. pp. 279-348 [R. T. Holman, editor]. Oxford: Pergamon Press.

Holman, R. T. (1973). Essential fatty acid deficiency in humans. In Dietary Lipids and Postnatal Development, pp. 127-143 [C. Galli, G. Jacini and A. Pecile, editors]. New York: Raven Press.

Holman, R. T. \& Aaes-Jorgensen, E. (1956). Effects of trans fatty acid isomers upon essential fatty acid deficiency in rats. Proceedings of the Society for Experimental Biology and Medicine 93, 175-179.

Johnston, P. V., Johnston, O. C. \& Kummerow, F. A. (1958). Deposition of in tissues and fecal excretion of transfatty acids in the rat. Journal of Nutrition 65, 13-21.

Kirstein, D., Hoy, C.-E. \& Holmer, G. (1983). Effect of dietary fats on the $\omega 6$ - and $\omega 5$-desaturation of fatty acids in rat liver microsomes. British Journal of Nutrition 50, $749-756$.

Kritchevsky, D. (1982). Trans-fatty acid effects in experimental atherosclerosis. Federation Proceedings 41, 2813-2817.

Kurata, N. \& Privett, O. S. (1980). Effects of dietary trans-acids on the biosynthesis of arachidonic acid in rat liver microsomes. Lipids 15, 1029-1036.

Lewis, R. A. \& Austen, K. F. (1981). Mediation of local homeostasis and inflammation by leukotrienes and other mast cell dependent compounds. Nature 293, 103-108.

Mahfouz, M. M., Johnson, S. \& Holman, R. T. (1980). The effect of isomeric trans-18:1 acids on the desaturation of palmitic, linoleic and eicosa-8,11,14-trienoic acids by rat liver microscomes. Lipids 15, 100-107.

Marzouki, Z. M. H. \& Coniglio, J. G. (1982). Effect of essential fatty acid deficiency on lipids of rat Sertoli and germinal cells. Biology of Reproduction 27, 312-315.

Mead, J. F. (1984). The non-eicosanoid functions of the essential fatty acids. Journal of Lipid Research 25 , I517-1521.

Menon, N. K., Moore, C. \& Dhopeshwarker, G. A. (1981). Effect of essential fatty acid deficiency on maternal, placental, and fetal rat tissues. Journal of Nutrition 111, 1602-1610.

Miller, R. G. (1981). Simultaneous Statistical Inference, pp. 1-229. Berlin: Springer Verlag.

Mohrhauer, H. \& Holman, R. T. (1967). Metabolism of linoleic acid in relation to dietary saturated fatty acids in rat. Journal of Nutrition $91,528-534$.

Moore, C. E., Alfin-Slater, R. B. \& Aftergood, L. (1980). Incorporation and disappearance of trans-fatty acids in rat tissues. American Journal of Clinical Nutrition 33, 2318-2323.

Nugteren, D. H. (1970). Inhibition of prostaglandin biosynthesis by 8-cis,12-trans, 14-cis-eicosatrienoic acid and 5-cis,8-cis, 12-trans, 14-cis-eicosatetraenoic acid. Biochimica et Biophysica Acta 210, 171-176. 
Nugteren, D. H., Christ-Hazelhof, E., van der Beek, A. \& Houtsmuller, U. M. T. (1985). Metabolism of linoleic acid and other essential fatty acids in the epidermis of the rat. Biochimica et Biophysica Acta 834, $429-436$.

Ohlrogge, J. B., Gulley, R. M. \& Emken, E. A. (1982). Occurrence of octadecenoic fatty acid isomers from hydrogenated fats in human tissue lipid classes. Lipids 17, 551-556.

Parlanti, 1. A. \& Orellana, L. C. (1985). The influence of an essential fatty acid deficient-diet on the reproductive performance of female rats. Reproduction, Nutrition, Développement 25, 851-860.

Pudelkewicz, C., Seufert, J. \& Holman, R. T. (1968). Requirements of the female rat for linoleic and linolenic acids. Journal of Nutrition 94, 138-146.

Ravel, D., Chambaz, J., Pepin, D., Manier, M. Ch. \& Bereziat, G. (1985). Essential fatty acid interconversion during gestation in the rat. Biochimica et Biophysica Acta 833, 161-164.

Satomi, S. \& Matsuda, I. (1973). Microsomal desaturation of linoleic into gamma-linoleic acid in livers of fetal, suckling and pregnant rat. Biology of the Neonate $22,1-8$.

Svaar, H. (1982). The long-term heart lesion phenomenon in animals and humans. In Nutritional Evaluation of Long-Chain Fatty Acids in Fish Oil, pp. 163-184 [S. M. Barlow and M. E. Stansby, editors]. London: Academic Press.

Thomassen, M. S., Rortveit, T., Christiansen, E. N. \& Norum, K. (1983). Changes in the content of n-6 fatty acids in liver phospholipids in rats as a consequence of partially hydrogenated dietary oils. British Journal of Nutrition 51, 315-322.

Walker, B. L. (1983). Fats in nutrition. Canadian Journal of Physiology and Pharmacology 61, 253-259.

Waltman, R., Tricomi, V., Shabanah, E. H. \& Arenas, R. (1978). Prolongation of rat gestation time by polyunsaturated fatty acids. American Journal of Obstetrics and Gynecology 131, 735-738.

Washington, W. J., Murthy, R. C., Doye, A., Eugene, K., Brown, D. \& Bradley, I. (1983). Induction of morphologically abnormal sperm in rats exposed to o-xylene. Archives of Andrology 11, 233-237.

Wilck, B. A. (1982). Dietary hydrogenated fat and lipogenic enzyme activity in rat tissues. M.Sc Thesis, University of Guelph, Guelph, Ontario, Canada

Wood, R. (1979). Distribution of dietary geometrical and positional isomers in brain, heart, kidney, liver, lung, muscle, spleen, adipose and hepatoma. In Geometrical and Positional Fatty Acid Isomers, pp. 213-281 [E. A. Emken and H. J. Dutton, editors]. Champaign, Ill. : American Oil Chemists' Society.

Zevenbergen, J. L., Houstmuller, U. M. T. \& Gottenbos, J. J. (1988). Linoleic acid requirement of rats fed trans fatty acids. Lipids $23,178-186$. 